\title{
HPV vaccine: knowledge and acceptance to ensure effectiveness
}

Oopen acess

'Disciplina de Ginecologia.

Departamento de Obstetrícia e

Ginecologia da Faculdade de Medicina

da Universidade de São Paulo.

${ }^{2}$ School of Nursing. University of

Missouri.

Corresponding author:

icesopreso@usp.br

Manuscript received: December 2017 Manuscript accepted: February 2018 Version of record online: March 2018
Isabel Cristina Esposito Sorpreso', Patricia Jane Kelly²

\begin{abstract}
The new Vaccine technologies against transmissible and non-transmissible diseases, such as cancer, have had an impact on international public health. The human papillomavirus (HPV) vaccine is used on a large scale in immunization programs in more than 58 countries, with resultant efficacy and safety for precursor lesions of cervical cancer, in addition to anogenital lesions. After the introduction of quadrivalent HPV vaccine $(6,11,16$ and 18) in Brazil in 2014, monitoring the vaccination coverage and the development of HPV prevalence incidence of cervical abnormalities and precancerous lesions must be observed, as well as morbidity and mortality trends from in situ and invasive cancer. Encouraging information, counseling and continuing education is recommended as a strategy to broaden vaccine acceptance in order to sediment its implementation and ensure effectiveness in reducing new cases of cervical cancer in the future.
\end{abstract}

Keywords: HPV, papillomavirus vaccines, human papillomavirus recombinant vaccine quadrivalent, types $6 ; 11 ; 16 ; 18$, uterine cervical neoplasms
Cervical cancer contributes to morbidity and mortality among women in Latin America; prevention, with early detection and health promotion essential in addressing the problem ${ }^{1,2}$. The estimated 16,340 new cases make cervical cancer the second most common neoplasm in the Northeast region ${ }^{3}$. The persistence of new cases and the high incidence in certain regions of the country are related to HPV (human papillomavirus) infection with high oncogenic risk (ability to cause pre-malignant lesions, in situ and invasive cancer), persistence of infection; contributing factors include low socioeconomic level, other genital infections, immunosuppression and genetic causes. The prevalence of high-risk oncogenic HPV in specific territories and populations combine with the ethnic or racial differences that exist in our country ${ }^{2-4}$. Research to identify the particulars in each territory are important for HPV prevention, early detection of precursor lesions and actions in health promotion as continuing education for professionals and health education in the self-care of the population in general and the vulnerable ${ }^{3,4}$. 
Since 2014, the National Immunization Program of the Ministry of Health (PNI-MS) has provided the quadrivalent HPV vaccine $(6,11,16$ and 18) for girls aged 9-14 years, including women living with HIV up to 26 years; 12 and 13 yearold boys and 9 to 26 year-old boys and men with HIV under medical guidance have also been added ${ }^{4}$. The primary prevention represented by condom use and a quadrivalent vaccine for HPV, as well as the advent of new vaccines (such as the "nonavalente" vaccine) represent a technological advance in health and a gain for women's health in the short and long term ${ }^{5}$.

Countries that have adopted the quadrivalent vaccine have reported reduction of precursor lesions from $60-80 \%$, with rates of $100 \%$ in populations vaccinated with the quadrivalent vaccine $(6,11,16$ and 18) for cases of genital warts ${ }^{5-7}$.

The optimal timing of vaccination for HPV is recommended prior to the first sexual contact of an individual. Vaccine efficacy in men and women suggests that immunization is more effective among individuals who have not been infected with HPV and reduces the morbidity of young women related to precursor lesions and cancer in situ ${ }^{8}$.

However, the vaccination coverage in the target population of adolescents before their initial sexual contact since the implementation of vaccine in the larger population, with percentages below $80 \%$ among adolescents in specific territories. That is below the expected and recommended by the WHO for the first and second dose ensuring the herd effect (benefits of the application of vaccines received by uninoculated people) $)^{9}$.

Understanding the factors that affect the HPV vaccination decision-making is critical if health promotion interventions are to be developed and address doubts, myths and fears of acceptance in population groups least likely to receive the HPV vaccine ${ }^{9,10}$.

Factors affecting the adequate vaccination coverage in a given population are examined at different socio-territorial levels that include political, community, organization, interpersonal (parent-child relationship), and intrapersonal (professional) relations ${ }^{10}$. In a recent review, Ferrer et $a l .{ }^{10}$, emphasized political factors, parents and guardians' decision, as well as the knowledge and counseling of health professionals as the main reasons in decision-making to obtain the vaccine for HPV. Still, these decisions are influenced by safety and efficacy of the vaccine; social norms and values related to sexual activity; confidence in vaccination programs and caregivers ${ }^{9,10}$. In our universal health system, individual financial limitations are not a significant influence in the decision-making since the vaccine is supplied to the target population without $\cos \mathrm{t}^{11}$.

In health facilities, health professionals' limited knowledge and skills in providing HPV vaccine could restrict a young woman's access to the vaccine regardless of her own beliefs and preferences $^{12}$. Health professionals represent, in some studies, the main providers of advice on the vaccine. The relationship between the practitioner and the decision-maker requires clear, accessible and sometimes culturally appropriate communication and information about the HPV vaccination program ${ }^{12,13}$.

Parents may decide not to allow their daughters to be vaccinated, based on cultural or religious perceptions, and the unsubstantiated correlation of the vaccine facilitating early sexual activity ${ }^{12,13}$. Identification of HPV vaccine knowledge gaps and acceptance barriers among adolescents, parents/ guardians and health professionals are necessary to develop targeted education programs for the lay population and continuing education in the work process of health professionals ${ }^{13,14}$.

Although young women are a critical part of the HPV vaccination program, the underrepresentation of their opinions in the qualitative literature should be considered in future research ${ }^{13}$. Health promotion activities should focus on the tripod of adolescents, parents/guardians and health care professionals to ensure adequate vaccine coverage and ensure the promising results of the vaccine.

The Journal of Human Grown Development (JHGD) brings the theme of health promotion in the scientific dissemination of articles and discusses necessary changes in the health-disease process, as in the study of Conception of the Right to Health of Mid-Level Technical Professionals of the Unified Health System In Brazil. The article reports on the biological model focused on the disease and medicalization as elements that still dominate in the Unified Health System policy ${ }^{15}$.

The permanent commitment of the journal JHGD to publish themes focused on healthy development inserted in the child and adolescent life cycle as the association of the prevalence of exposure to fluoride in the nails of children's hands with dental fluorosis ${ }^{16-18}$; between delayed neuropsychomotor development and infants of street drug users ${ }^{19}$ and the association of adequate growth with lipid profiles ${ }^{20}$.

The journal JHGD presents the importance of the concept of reproductive planning and preconception planning as a health promotion for children, as well as for the current situation of teenage pregnancy and the association with arterial hypertension ${ }^{21,22}$. Sexual and reproductive rights are 
considered in the cited article on the repercussions of Zika virus during pregnancy ${ }^{23}$. In the field of public health, the journal discloses the importance of identifying risk to provide quality care for chronic diseases ${ }^{24}$ and non-communicable diseases as well as the indiscriminate use of antibiotics ${ }^{25}$.
The perception and involvement of children and adolescents in clinical research, consent and assent and shared decision-making must be present in the development and planning of actions in health promotion for this population.

\section{REFERENCES}

1. McGuire S. World Cancer Report 2014. Geneva, Switzerland: World Health Organization, International Agency for Research on Cancer, WHO Press, 2015. Adv Nutr. 2016;7(2):418-9. DOI: http://dx.doi.org/10.3945/an.116.012211

2. Instituto Nacional de Câncer José Alencar Gomes da Silva (INCA). Câncer: colo do útero. [cited 2018 feb 27] Available from: http://www2.inca.gov.br/wps/wcm/connect/tiposdecancer/site/home/colo_utero

3. Nascimento MDDSB, Vidal FCB, Silva MACND, Batista JE, Barbosa MDCL, Muniz Filho WE, et al. Prevalence of human papillomavirus infection among women from quilombo communities in northeastern Brazil. BMC Women's Health. 2018;18(1):1. DOI: http://dx.doi.org/10.1186/s12905-017-0499-3

4. Brasil. Ministério da Saúde. Vacinação. [cited 2018 feb 22] Available from: http://portalms.saude.gov.br/ acoes-e-programas/vacinacao/calendario-nacional-de-vacinacao

5. Castle PE, Maza M. Prophylactic HPV vaccination: past, present, and future. Epidemiol Infect. 2016;144(3):449-68. DOI: http://dx.doi.org/10.1017/S0950268815002198

6. Garland SM, Hernandez-Avila M, Wheeler CM, Perez G, Harper DM, Leodolter S, et al. Quadrivalent vaccine against human papillomavirus to prevent anogenital diseases. N Engl J Med. 2007;356(19):1928-43. DOI: http://dx.doi.org/10.1056/NEJMoa061760

7. The Future II Study Group. Quadrivalent vaccine against human papillomavirus to prevent high-grade cervical lesions. N Engl J Med. 2007;356(19):1915-27. DOI: http://dx.doi.org/10.1056/NEJMoa061741

8. Markowitz LE, Dunne EF, Saraiya M, Chesson HW, Curtis CR, Gee J, et al. Human papillomavirus vaccination: recommendations of the Advisory Committee on Immunization Practices (ACIP). MMWR Recomm Rep. 2014;63(RR-05):1-30.

9. Human papillomavirus vaccines. WHO position paper. Wkly Epidemiol Rec. 2009;84(15):118-31.

10. Ferrer HB, Trotter C, Hickman M, Audrey S. Barriers and facilitators to HPV vaccination of young women in high-income countries: a qualitative systematic review and evidence synthesis. BMC Public Health. 2014;14:700. DOI: http://dx.doi.org/10.1186/1471-2458-14-700

11. Novaes HM, Soárez PC, Silva GA, Ayres A, Itria A, Rama CH, et al. Cost-effectiveness analysis of introducing universal human papillomavirus vaccination of girls aged 11 years into the National Immunization Program in Brazil. Vaccine. 2015;33(Suppl 1):A135-42. DOI: http://dx.doi.org/10.1016/j.vaccine.2014.12.031

12. Perkins RB, Brogly SB, Adams WG, Freund KM. Correlates of human papillomavirus vaccination rates in low-income, minority adolescents: a multicenter study. J Womens Health. 2012;21(8):813-20. DOI: http://dx.doi.org/10.1089/jwh.2011.3364

13. Bynum SA, Staras SA, Malo TL, Giuliano AR, Shenkman E, Vadaparampil ST. Factors Associated with Medicaid Providers Recommendation of the HPV Vaccine to Low-Income Adolescent Girls. J Adolesc Health. 2014;54(2):190-6. DOI: http://dx.doi.org/10.1016/j.jadohealth.2013.08.006

14. Sousa PDL, Takiuti AD, Baracat EC, Sorpreso ICE, Abreu LC. Knowledge and acceptance of $\mathrm{HPV}$ vaccine among adolescents, parents and health professionals: construct development for collection and data base composition. J Hum Growth Dev. 2018; 28(1):58-68. DOI: http://dx.doi.org/10.7322/jhgd.143856

15. Melo RMSB, Morais GB, Morais JB, Leite SN. Conception of the Right to Health of Mid-Level Technical Professionals of Unified Health System In Brazil. J Hum Growth Dev. 2018; 28(1):95-104. DOI: http://dx.doi.org/10.7322/jhgd.143886

16. Leite JC, Neves JCJ, Vitor LGV, Fujisawa DS. Evaluation of postural control in children and adolescents with Down Syndrome aged eight to twelve years old. J Hum Growth Dev. 2018; 28(1):50-7. DOI: http://dx.doi.org/10.7322/jhgd.127335 
17. Bessa ARS, Dotto LMG, Cunha MA, Muniz PT, Cavalcante SO. Delivery and postpartum care in Rio Branco in the northern state of Acre, Brazil: a populationbased survey. J Hum Growth Dev. 2018; 28(1):69-76. DOI: http://dx.doi.org/10.7322/jhgd.118010

18. Rigo L, Cericato GO, Sabadin CS, Solda C, Mário DN, Buzalaf MAR. Fingernails as a biomarker for dental fluorosis. J Hum Growth Dev. 2018; 28(1):82-8. DOI: http://dx.doi.org/10.7322/jhgd.133582

19. Lima RE, Aleixo AA, Araújo LB, Nascimento CP, Azevedo VMGO. Neuropsychomotor development characteristics of the infants who born from women who abused drugs during pregnancy. J Hum Growth Dev. 2018; 28(1): 27-34. DOI: http://dx.doi.org/10.7322/jhgd.134374

20. Guedes-Granzotti RB, Siqueira LS, Cesar CPHAR, Silva K, Domenis DR, Dornelas R, et al. Neuropsychomotor development and auditory skills in preschool children. J Hum Growth Dev. 2018; 28(1):35-41. DOI: http://dx.doi.org/10.7322/jhgd.123380

21. Pinto VCM, Santos PGMD, Medeiros RCSC, Souza FES, Simões TBS, Dantas RPNC, et al. Maturational stages: comparison of growth and physical capacity indicators in adolescentes. J Hum Growth Dev. 2018; 28(1):42-9. DOI: http://dx.doi.org/10.7322/jhgd.127411

22. Barreto GMS, Balbo SL, Rover MS, Toso BRGO, Oliveira HR, Viera CS. Growth and biochemical markers of newborn preterm up to six months of corrected age. J Hum Growth Dev. 2018; 28(1):18-26. DOI: http://dx.doi.org/10.7322/jhgd.138687

23. Prata ARS, Pedroso D, Menezes G, Drezett J, Torres JHR, Bonfim JRA, et al. Juridical perspectives of interruption of pregnancy with zika virus infection regarding medical, emotional and social consequences. J Hum Growth Dev. 2018; 28(1): 77-81. DOI: http://dx.doi.org/10.7322/jhgd.143875

24. Almeida RC, Zachêu PRZ, Diniz MT, Dias MCCPO, Guiguer IC, Almeida RC, Corrêa JA. Portuguese translation and Brazilian cultural adaptation of the Assessment of Burden in Chronic Venous Disease questionnaire (ABC-V) . J Hum Growth Dev. 2018; 28(1):89-94. DOI: http://dx.doi.org/10.7322/jhgd.143885

25. Okasaki R, Carvalho WB, Ceccon MEJR. Newborns with staphylococcus aureus and coagulase-negative sepsis treated with vancomycin after an increase in serum levels in around the valley. J Hum Growth Dev. 2018; 28(1):9-17. DOI: http://dx.doi.org/10.7322/jhgd.143846

\section{Resumo}

As novas tecnologias em vacina contra doenças transmissíveis e não transmissíveis como o câncer, tiveram impacto na saúde pública internacional, especificamente a vacina para o papiloma vírus humano (HPV) utilizada em larga escala nos programas de imunização em mais de 58 países, com resultados de eficácia e segurança para lesões precursoras do câncer de colo do útero além de lesões anogenitais. Após a introdução em território Nacional da vacina quadrivalente para o $\operatorname{HPV}(6,11,16$ e 18) desde 2014 , ressalta-se a importância do monitoramento da cobertura vacinal e o desenvolvimento de estudos de prevalência de HPV em logo prazo, de incidência de anormalidades cervicais e lesões pré-cancerosas bem como de tendência de morbimortalidade por câncer in situ e invasivo. O incentivo às informações, aconselhamento e educação continuada é recomendado como uma estratégia para ampliar a aceitação da vacina a fim de sedimentar sua implantação e assegurar a eficácia na redução dos novos casos de câncer de colo do útero para o futuro.

Palavras-chave: HPV, vacinas contra papillomavirus, vacina quadrivalente recombinante contra HPV tipos $6,11,16,18$, neoplasias do colo do útero. 